\title{
Speculation and the Informational Efficiency of Commodity Futures Markets
}

\author{
Martin Bohl ${ }^{\dagger}$, Alexander Pütz ${ }^{\dagger}$, Christoph Sulewski ${ }^{\dagger}$
}

$89 / 2019$

${ }^{\dagger}$ Department of Economics, University of Münster, Germany

wissen.leben

WWU Münster 


\title{
Speculation and the Informational Efficiency of Commodity Futures Markets
}

\author{
Martin T. Bohl, Alexander Pütz, Christoph Sulewski
}

Tuesday $15^{\text {th }}$ October, $201913: 49$

\begin{abstract}
The recent financialization in commodity futures markets has prompted many calls for restricting speculative activity due to its diametrical effect on market quality. One aspect of market quality is that new information is instantanously reflected in the price. This article studies how speculative activity affects informational efficiency of commodity futures markets. We document significant temporal and cross-sectional variation in market efficiency in 20 commodity futures markets based on a sample of weekly closing prices from 1986 to 2019. The fixed effects panel regression finds no evidence for a significant relation between speculative activity and the degree of informational efficiency after controlling for volatility and liqudity. The results are robust across different window sizes, sampling frequencies and levels of trader aggregation.
\end{abstract}

JEL Classification: G14, G15, C12

Keywords: Market efficiency, Variance ratio test, Commodity futures

${ }^{*}$ For helpful comments and discussions we would like to thank Nicole Branger, Pierre L. Siklos, Claudia Wellenreuther, Martin Stefan and Markus Herrmann. 


\section{Motivation}

The past decade has seen in commodity markets a rapid increase in trading volumes in conjunction with unprecedented large fluctuations and excess co-movement. As a result, policy makers and scholars have renewed their interest in the study of commodity markets. The 5 general perception is that this significant change in commodity price behaviour is primarily caused by a sharp increase in speculative activity in commodity futures markets. The debate prompted many calls for restrictions on trading positions in order to limit speculative activity. Nevertheless, the academic literature has so far not settled on the question whether speculators or macroeconomic fundamentals were mainly responsible for the severe fluctuations in commodity prices.

The issue of speculation has received considerable critical attention by the literature. Several attempts have been made to investigate the influence of speculative activity on price dynamics (Brunetti et al., 2016; Manera et al., 2016), excess co-movement (Le Pen and Sévi, 2018; Büyükşahin and Robe, 2014) or risk premia (Hamilton and Wu, 2014). Nevertheless, little is known about the influence of speculative trading on the efficiency of commodity futures markets. Market efficiency is one of the building blocks of modern financial theory, since more informative prices fasciliate more efficient and better-informed capital allocation decisions.

Two different mechanisms are conceivable that could link speculative activity to market efficiency. First, microstructure theory suggests that security prices react to informationmotivated trading (e.g., Glosten and Milgrom, 1985; Kyle, 1985), and information-motivated trading in turn should fasciliate information efficiency. In case that speculators primarily act on proprietary information, then their trading behaviour should fasciliate market efficiency with prices moving closer to fundamental values. On the contrary, speculators may consist of poorly informed noise traders (e.g. De Long et al., 1990), whose order flow impedes information transmission. For instance, Grossman and Miller (1988) argue that feedback trading of noise trader entails positive return autocorrelation. Moreover, it is conceivable 
that non-informed trading leads to negative return autocorrelation. Suppose that the noninformed trading of noise traders pushes prices far beyond their equilibrium level. When fundamental information becomes available, noise traders' subsequent trading pushes prices back to their fundamentally justified level (Poterba and Summers, 1988). The commodity futures markets provide an interesting testing labroratory to investigate the influence of trading motivation (speculation or hedging) on market efficiency due to the identifiable diverging trading incentives.

Second, market efficiency is closely related to liquidity provision (Chordia et al., 2008) since deteriorating liquidity increases trading costs and makes arbitrage activity less attractive. ${ }^{1}$ This in turn, leads presumably to less efficient markets. Consequently, security prices should reflect fundamental information more accurately in case market liquidiy is higher. One of the key features of speculative activity is liquidity provision in that speculators act as counterparts for hedging needs fasciliting efficient risk allocation in financial markets. For instance, Sanders et al. (2010) and Chen and Chang (2015) show that speculative activity is positively related to liquidity. Therefore, we expect that from a liquidity provider perspective speculators should enhance market efficiency.

This paper investigates the impact of speculative and hedging activity on informational efficiency in a sample of 20 major commodity futures markets spanning the period January 1986 to May 2019. Drawing upon recent improvements in the literature, we test for return predictability by utilizing the Choi (1999) automatic variance ratio test (AVR). Time-varying measures of market efficiency are derived through rolling-window estimations. Subsequently, the interrelation between trading motive and informational efficiency is examined. The derived measure of market efficiency is regressed on selected variables that capture different aspects of speculative and hedging activity. We consider the total market share (in terms of open interest) of speculators and hedgers. Furthermore, we adopt the Working's (1960) T index to quantify the degree of excessive speculation. To construct the suggested measures of

$\overline{1}$ Trading costs are related to liquidity in two ways. First, lower levels of liquidity widen generally the bid-ask spread. Second, trading activity in less liquid markets moves prices more adversely. 
trading motive, we utilize information on trader positions that is provided by the Commodity

\subsection{Market inefficiency and return autocorrelation}

To date, the literature has highlighted various ways how to assess the elusive concept of market efficiency. This paper adopts the definition of Fama (1970), which builds on the idea that new information is instantanously and fully reflected in the price. For this reason, price series should not exhibit any form of serial correlation. The presence of autocorrelation in the return process would indicate misreaction by investors to new information that is not conceivable with the concept of market efficiency. This notion is supported by different 
theoretical models and frequently adopted in empirical studies. ${ }^{2}$

According to De Long et al. (1990), overreaction of market participants to new information may be associated to positive return autocorrelation. Conversely, Froot et al. (1995) argue that positive serial correlation arises due underreaction in the form of slow dissemination of market-wide information. Moreover, it is conceivable that systematic behavioural biases may affect traders to under- or overreaction to the arrival of new information (see, among others, Barberis et al., 1998). The presence of significant autocorrelation structures in the return process is further illustrated by the well documented profitability of contrarian (De Bondt and Thaler, 1985) and momentum trading strategies (Jegadeesh and Titman, 1993). Such trading strategies should not be rewarded with a significant positive return in informationally efficient markets.

\section{$2.2 \quad$ Variance Ratio Test}

The literature has proposed a variety of measures to quantify the degree of informational efficiency. Since the presence of serial correlation is closely related to the random walk model, we first recapitulate the random walk model to build the stage for our empirical approach. The random walk process assumes that the dynamics of the price series $\left\{P_{t}\right\}$ can be formulated as follows:

$$
P_{t}=\mu+P_{t-1}+\epsilon_{t}
$$

where $\mu$ denotes the constant drift term, capturing the expected price change, and $\epsilon_{t}$ is the error term with zero mean and variance $\sigma^{2}$. By utilizing recursive substitions of lagged $P_{t}$,

2 While this notion of market efficiency is adopted in various theoretical and empirical studies, oponents argue that the presence of return autocorrelation itself does not necessary indicate market inefficiencies. For instance, serial return correlation is conceivable with rational information processing by market participants and not exploitable due to trading frictions (e.g. short sale restrictions, trading costs) (Jensen, 1978). A different strand of the literature argues that the serial return correlation may only reflect time-varying equilibrium expected returns. 
mean and variance at time $t$, conditional on an initial value $P_{0}$, are given as follows:

$$
\begin{aligned}
E\left[P_{t} \mid P_{0}\right] & =P_{0}+t \mu \\
\operatorname{Var}\left[P_{t} \mid P_{0}\right] & =\sigma^{2} t .
\end{aligned}
$$

Evidently, conditional mean and variance of a random walk process depend on the time horizon $t$, which implies that a random walk is not stationary. An additional characteristic of the random walk model is that consecutive price increments are not forecastable based on the past history of $\left\{P_{t}\right\}$ and i.i.d. random variables:

$$
P_{t}-P_{t-1}=\epsilon_{t}
$$

The variance ratio test (VR), that was initially proposed by Lo and MacKinlay (1988) and that we adopt to measure the degree of market efficiency, rests on the notion that, if price increments follow a random walk, then the return variance is a linear function of $t$. Hence, the $q$-period return variance should correspond to the return variance over one period multiplied with holding period $q$. In general, the VR is defined as:

$$
\operatorname{VR}(q)=\frac{\operatorname{Var}\left[r_{t}(q)\right]}{q \operatorname{Var}\left[r_{t}\right]}
$$

where $r_{t}(q)=r_{t}+r_{t-1}+\cdots+r_{t-q+1}$. In case the return process follows a random walk, then the VR should take values equal to unity. The VR is also closely related to the autocorrelation structure of the return process. This becomes apparent if we reformulate (4) as:

$$
V R(q)=1+2 \sum_{k=1}^{q-1}\left(1-\frac{k}{q}\right) \rho(k),
$$

where $\rho(k)$ denotes the $k$ th order autocorrelation coefficient of $\left\{r_{t}\right\}$. Thus, the VR can be summarized as one plus a weighted average of the first $q-1$ autocorrelation coefficients $\left\{r_{t}\right\}$. Under the null hypothesis that the price follows a random walk process, $V R(q)$ takes values equal to unity, because price changes are serially uncorrelated. 
A main advantage of the VR test over the frequently cited competing alternative BoxPierce test is that it indicates the sign of serial correlation. A VR ratio below unity indicates that returns are overall negatively serially correlated, whereas a value above unity provides evidence for positive autocorrelation. As a metric for relative efficiency, the literature (Boehmer and Kelley, 2009; Rösch et al., 2017) employs the absolute deviation of the VR from unity, since relatively more efficient prices should exhibit less autocorrelation.

\subsection{Automatic Variance Ratio}

The adoption of the $V R$ test requires the selection of a specific value for the holding period $q$. However, the choice of $q$ is often made arbitrarily. Concerning this drawback, Choi (1999) suggests the automatic variance ratio $(A V R)$ test, which rests on a fully data-dependent method for choosing $q$ optimally:

$$
V R(q)=1+2 \sum_{i=0}^{T-1} k\left(\frac{i}{q}\right) \rho(i)
$$

where $\rho(i)$ defines the autocorrelation coefficient of order $i$. For the weighting function $k(\cdot)$, which is characterized by positive and declining weights, Choi (1999) proposes the adoption of a quadratic spectral kernel:

$$
k(x)=\frac{25}{12 \pi^{2} \chi^{2}}\left[\frac{\sin (6 \pi \chi)}{6 \pi \chi / 5}-\cos \left(\frac{6 \pi \chi}{5}\right)\right] .
$$

According to Choi (1999), the $A V R(k)$ is asymptotically equivalent to $2 \pi f_{Y}(0)$, where $f_{Y}(0)$ denotes the normalized spectral density at zero frequency for return series $\left\{r_{t}\right\}$. Testing the null hypothesis that the $V R$ is equal to unity requires choosing the value of holding period $q$. To circumvent the arbitrary choice of $q$, Choi (1999) adopts the data-dependent method of Andrews (1991). For the sake of brevity, we refer to Choi (1999) for a thorough description of the Andrews (1991) selection method. In the subsequent empirical analysis, we employ the absolute deviation of the $A V R(q)$ from unity as the dependent variable to assess 
the influence of speculative activity on the degree of informational efficiency in commodity futures markets. This metric is an inverse measure, as higher values indicate lower degress of informational efficiency.

Time varying measures of market efficiency are derived by conducting moving-window analysis with a fixed length of 250 weekly observations, which corresponds to roughly five calendar years. However, we are aware of the possibility that our results may be driven by the choice of window size. Therefore, we conduct as a robustness check the empirical analysis with alternative window sizes of 100 and 400 weeks, which correspond to 2 and 8 years.

\section{Data}

\subsection{Commodity Futures Data}

For the purpose of this study, we construct a sample comprising twenty commodity futures markets. The choice of commodity markets is based on their coverage in the CFTC COT reports. Representative for the energy sector, we consider crude oil, natural gas and heating oil. The agricultural sector is represented by CBOT wheat, corn, KCBT wheat, soybeans, coffee, cocoa, cotton, sugar, feeder cattle, lean hogs and live hogs. For metals, we include gold, palladium, platinum, silver, and copper. Thus, our data include three energy products, five metals, and eleven agricultural commodities. The selected commodity futures contracts are traded at the Chicago Board of Trade (CBOT), the Kansas Board of Trade (KCBT), the Intercontinental Exchange (ICE), the New York Commodities Exchange (COMEX), and the New York Mercantile Exchange (NYMEX). All price series are retrieved from Datastream. Price quotations are in USD and represent daily closing prices. Continuous futures prices series are obtained by rolling over to the next nearby contract on the first trading day of the expiring month. The sample period spans from January 1986 to May 2019. The start date is confined by the availability of the COT report, which was initially introduced in January 1986 for selected commodities and extended in scope in the following years. We 
utilize weekly data and compute tests on a weekly frequency. ${ }^{3}$

\section{[FIGURE 1 about here]}

Figure 1 depicts the evolution of futures market prices across the different markets and grouped by commodity sub-sector. For energy and metal commodities, the illustrated price process reflects inner-sectoral co-movement as well as pronounced spikes and crashes in the respective markets. While energy and metal prices were stable during the 1990s, they have risen sharply since then. The agricultural sub-sectors grain \& oil seeds, livestock and softs exhibit compareable dynamics with substantial co-movement. However, in contrast to energy commodties, we observe no persistent increase in agricultural prices before 2005.

Since computation of market efficiency measures relies on return figures, we derive weekly returns as the log difference of weekly prices as follows:

$$
R_{i, w}=\ln \left(\frac{p_{i, w}}{p_{i, w-1}}\right)
$$

where $p_{i, w}$ denotes the price of market $i$ in week $w$. Table 1 presents descriptive statistics of the weekly logarithmic futures returns. Roughly two thirds of all return series exhibit a negative skewness, suggesting that severe price drops are more common than large price increases. For all return series we observe kurtosis values well in excess of 3, which is the reference kurtosis value of the normal distribution. This implies that none of the series follow a normal distribution, but feature fat tails instead. Lastly, we examine the stationarity properties of each futures return series by conducting the ADF test. Our test results unequivocally indicate that commodity prices are stationarity in first differences.

3 In a robustness exercise, we repeat the analysis employing daily return data. For each sub-sample, we derive the absolute deviation of the automatic variance ratio from unity and then move the window by one week. In this way, we derive a weekly measure of market efficiency based on daily autocorrelations. 


\subsection{Measures of speculation}

The Commodity Futures Trading Commission (CFTC) provides trader position data in the Commitment of Traders (COT) report on a weekly basis. More specifically, the COT report includes information on end-of-day open interest on a specified trading day per week (usually

185 The different trader categories can be defined as follows:

1. Commercial trader: Frequently named as hedger. The commercial trader is assumed to have a physical interest in the underlying commodity spot market.

2. Non-commercial trader: Primarily defined as speculators with no inherent physical interest in the underlying spot market.

3. Non-reporting traders: Not obligated to disclose the nature of their trading to the CFTC since their holdings do not exceed the minimum reporting threshold defined by the CFTC.

In accordance with the literature (e.g., Bessembinder, 1992; De Roon et al., 2000), we refer

to commercial and non-commercial traders as hedgers and speculators, respectively.

The literature offers a variety of measures to quantify the degree of speculation. Among others, Manera et al. (2016) suggest the percentage of open interest held by traders with assumed speculative intentions as a proxy for speculative intensity. The measure can be computed as follows:

$$
S_{t}=\frac{N C L_{t}+N C S_{t}+\alpha \times\left(N R L_{t}+N R S_{t}\right)}{2 \times M O I_{t}} \times 100
$$

where $N C L_{t}$ and $N C S_{t}$ denote the long and short position held by non-commercial traders, respecively. Further, $N R L_{t}$ and $N R S_{t}$ are the long and short positions held by non-reporting traders, whereas $\alpha$ captures the share of non-reporting traders that are assumed to follow speculative intentions. However, the adequate choice of $\alpha$ is somehow arbitrary. Concerning 
this matter, we follow Sanders et al. (2010) and assume the proportion of speculators among non-reporting traders to be equal to the porportions observed for reporting traders.

A measure, that is commonly applied in the literature to gauge excessive speculative activity, is the Working (1960) T index (herafter $\left.W_{t}\right)$ :

$$
W_{t}= \begin{cases}1+\frac{S S_{t}}{H S_{t}+H L_{t}}, & \text { if } H S_{t} \geq H L_{t} \\ 1+\frac{S L_{t}}{H S_{t}+H L_{t}}, & \text { if } H S_{t}<H L_{t}\end{cases}
$$

where $S L_{t}\left(H L_{t}\right)$ and $S S_{t}\left(H S_{t}\right)$ denote the long and short open interest held by speculators (hedgers). The positions are computed as follows:

$$
\begin{aligned}
S L_{t} & =N C L_{t}+\alpha \times N R L_{t} \\
S S_{t} & =N C S_{t}+\alpha \times N R S_{t} \\
H L_{t} & =C L_{t}+(1-\alpha) \times N R L_{t} \\
H S_{t} & =C S_{t}+(1-\alpha) \times N R L_{t} .
\end{aligned}
$$

The rational for the Working's $\mathrm{T}$ is that each hedging position is backed by a corresponding speculation position. In case long and short positions of hedgers do not offset each other $\left(H S_{t} \neq H L_{t}\right)$, then speculators are required to meet excess hedging demand so that the market is cleared. In this context, excessive speculation is defined as the situation in which speculators take positions surpassing the inherent market inbalance. Increasing values for the Working's T indicate higher levels of excessive speculation.

While we are mainly interested in the effect of speculative activity on informational efficiency, we also derive two metrics of hedging intensity. The first measure is calculated as the total proportion of open interest held by market participants identified as commercial traders. Therefore, the total open interest share of traders identified as hedgers, $H_{t}$, can be derived as follows:

$$
H_{t}=\frac{C L_{t}+C S_{t}+(1-\alpha) \times\left(N R S_{t}+N R L_{t}\right)}{2 \times M O I_{t}} \times 100 .
$$


The second metric that we consider to measure the degree of hedging activity is hedging pressure. The net position held by hedgers is commonly regarded as hedging pressure. Following De Roon et al. (2000) and Acharya et al. (2013), we derive the hedging pressure as follows:

$$
H P_{t}=\frac{C S_{t}+(1-\alpha) \times N R S_{t}-C L_{t}-(1-\alpha) \times N R L_{t}}{C S_{t}+(1-\alpha) \times N R S_{t}+C L_{t}+(1-\alpha) \times N R L_{t}}
$$

Complementing the COT report, the CFTC started in 2006 to release a weekly Commodity Index Trader (CIT) report for a smaller subset of thirteen agricultural commodities. This report provides insight into the trading positions of index trader who were debated vigorously in public and academic discussions. In a robustness exercise, we employ the CIT data and repeat the analysis for index and non-index speculators. To quantify the extent of index trader activity, we compute the total share of open interest held by index traders and split the group of non-reportable traders according to the procedure utilized for the overall sample.

\section{Time-varying return predictability}

In order to assess the relationship between speculation and market efficiency, the following regression model is estimated:

$$
\left|A V R_{i, t}-1\right|=\alpha+\gamma A R+\beta_{1} T O_{i, t}+\beta_{2} V O L_{i, t}+\beta_{3} I_{l l i q_{i, t}}+\beta_{4} \operatorname{Spec}_{i, t}+\mu_{t}+\phi_{i}+\epsilon_{i, t},
$$

where $\left|A V R_{i, t}-1\right|$ denotes the measure of informational efficiency for commodity futures contract $i$ in week $t, T O_{i, t}$ is the turnover ratio scaled by open interest, and $V O L_{i, t}$ the market volatility based on the conditional volatility estimates of an $\mathrm{AR}(1)$ - $\mathrm{GARCH}(1,1)$ model. Furthermore, Illiq $_{i, t}$ is a measure for illiquidity proxied by the Amihud (2002) ratio, and Spec $_{i, t}$ denotes a proxy for speculative/hedging activity. Further, we control for common shocks in a given year by including year-specific dummies $\left(\mu_{t}\right)$ and for time invariant commodity specific heterogeinity (such as storability of the commodity or different market mechanism frameworks) by including time-invariant commodity-specific fixed effects 
$\left(\phi_{i}\right)$. Lastly, $\epsilon_{i, t}$ is the error term. We allow for clustering among observations of the same commodity market and add the lagged dependent variable to the regression equation since ensure that the present autocorrelation does not bias the regression results.

[TABLE 2 about here]

\subsection{Variation of informational efficiency}

The dependent variable of (14) is the absolute deviation of the automatic variance ratio from unity. This measure quantifies the magnitude of the commodity futures price deviation from the random walk benchmark model. Table 2 reports descriptive statistics for the dependent and independent variables in (14).

\section{[FiguRE 2 about here]}

To illustrate the evolution of informational efficiency, Figure 2 depicts the time series of the dependent variable over the sample period for each commodity market. Overall, most of the commodity futures markets show prolonged periods in which the $A V R$ clearly deviates from unity. However, the results do not point to a clear trend across all commodities. Even at the commodity sub-group level (e.g. grains, livestock and softs) a common trend is hardly identifiable. To identify a structual break since the onset of the financialization period, Table 3 reports for each commodity market the mean absolute deviation of the $A V R$ from unity for the total sample, a sub-sample spanning the pre-financialization period up to 2003 and a sub-sample covering the financialization period. ${ }^{4}$ From Table 3 , it becomes obvious that the dawn of the financialization period does not constitute a structural break in the degree of informational efficiency.

Taken together, the Figure 2 and Table 3 results stand in sharp contrast to common public

$4 \quad$ Among others, Hamilton and Wu (2015) claim that the finanacialization of commodity markets started during 2004-2005 period. 
opinion that the financialization period and the accompanied emergence of commodities as an asset class did harm market quality in commodity futures markets.

[TABLE 3 about here]

\subsection{Speculation and Informational Efficiency}

Table 4 reports coefficient estimates for different specifications of (14). Column (1) shows the most parsimonious model with only a constant and the total percentage of open interest held by non-commercial investors as a proxy for speculative activity. The coefficient estimate is significant at the $10 \%$ level, and the negative sign suggests that speculators improve market efficiency. This relationship holds even after inlcuding the lagged dependent variable (at the $5 \%$ level). However, the observed effect vanishes after including time- and market-specific fixed-effects and control variables (see Column (3)).

[TABLE 4 about here]

Concerning the control variables, we observe that the turnover ratio is highly significant (at the 1\%-level) with a negative sign. This observation is consistent with the literature correlation (e.g. Campbell et al., 1993). Diminishing liquidity is related to increasing serial return correlation and hence less informationally efficient markets. For instance, Chordia et al. (2000) show that frequently traded securities react faster to the arrival of new information. Table 4 reports similar results for the alternative proxy of market liquidity based on the Amihud (2002) metric. An increase in the degree of liquidity (decrease of the Amihud (2002) ratio) is associated with a smaller deviation of the $A V R$ from unity and hence greater informational efficiency.

The level of market volatility is positively associated with market inefficiency at the 1\%level. This observation contrasts the prediction of the Sentana and Wadhwani (1992) model. 
However, the sign is justifiable from an economic perspective. According to Shiller (1981), noise rather than the arrival of new information is primarily responsible for excessive levels of return volatility. In the context of the Chan (1993) model, securities with noisy signals tend to incorporate new information more slowly. This is also consistent with McQueen et al. (1996), who document that market volatility is positively associated with a price delay measure.

Subsequently, we repeat the regression analysis but adopt the Working's T index as a measure for speculative activity. Columns (4)-(6) present the coefficient estimates for excessive speculation. The results are consistent with the estimates obtained for the total market share of speculators. In the baseline model, the coefficient estimate for the Working's T index is negative and highly significant. However, after the inclusion of fixed effects and control variables, the coefficient estimate turns insignificant. This illustrates, that even speculative activity beyond just providing liquidity for hedging needs of commercial traders is not related to the degree of informational efficiency after controlling for market state variables and unobserved time- and market-specific heterogeinity. However, this implies also that speculators do not harm the process of how markets respond to the arrival of new information.

[TABLE 5 about here]

The coefficient estimates concerning the influence of market participants with a commercial interest in the underlying commodity (hedger) on the informationally efficiency are reported in Table 5. In general, we find that hedging activity measured by the total share of open interest held by commercial traders is positive and significantly related to informational inefficiencies before controlling for market state variables. However, after controlling for liquidity, volatility and unobserved heterogeinity, the significant effect vanishes. This implies, that hedgers do not affect market efficiency beyond their association with market states. Conceivably, hedgers may decrease the general level of market liquidity due to the nature of their trading, which is demanding liquidity for hedging trades. 
As mentioned before, the moving-subsample approach requires choosing a window size. In order to investige the robustness of our results, we repeat the analysis with alternative window lengths. Namely, we reestimate the regression models with window sizes of 100 and 400 weeks, which correspond to 2 and 8 years, respectively. Tables 6 and 7 show the coefficient estimates with alternative window sizes for speculative activity and Tables 8 and 9 for hedging intensity.

\section{[TABLES 6 AND 7 about here]}

In general, the results are robust across the different window lengths. Speculative activity (total \& excessive) is not associated with the degree of infromational efficiency in commodity markets. However, the observed positive effect on informational efficiency before controlling for market states is only present in the 400 weeks window regression. The same applies to hedging activity, where the negative influence of total hedging activity turns insignificant in the baseline model with 400 weeks.

\section{[TABLES 8 AND 9 about here]}

A final concern may be the data frequency for that the autocorrelation structure is evaluated. Therefore, we repeat the earlier analysis and derive the $A V R$ based on daily data. In order to match the daily series of $A V R$ with the COT data, which is solely available on a weekly basis, we estimate the $A V R$ for a sub-sample of 1000 days (which corresponds to our choice of 250 weeks) and after the $A V R$ is estimated for the first sub-sample, the window is moved by one week.

\section{[TABLES 10 AND 11 about here]}

Again, the results for the influence of speculative and hedging activity on market efficiency remain robust (see Tables 10 and 11). In principle, speculative activity does neither harm 
nor improve market efficiency, especially after controlling for market volatility and liquidity.

\subsection{Index Trading, Speculation and Informational Efficiency}

The discussions around the financialization of commodity markets focus mainly on the question whether long-only index investors diametrically affected market quality in commodity futures markets. In the preceding analysis, we considered speculators as a merely homogenous group. However, it may be conceivable for instance that index traders affect market efficiency differently than classic long-short speculators. Index trader may only react to the demand of investors to gain exposure to the commodity sector due to its diversifying ability, while long short speculators may actually trade on information.

[TABLE 12 about here]

Addressing this conceivable concern, we repeat the analysis employing the Supplemental Commitment of Traders (SCOT) report, which is published by the CFTC for a smaller subset of 13 agricultural commodities since 2006 on a weekly basis. While the cross-sectional and temporal dimension of the data set is rather limited compared to the one we employed in the earlier analysis, it may reveal some interesting insight concerning the suggested disparate trading effect of index and long-short speculators.

Table 12 reports the findings of repeating the analysis for the more disaggregated dataset. In general, we find that even after disaggregating the group of speculators in long-only index investors and long-short speculators, speculators are not associated with any variation in informational efficiency after controlling for market state variables.

Taken together, we cannot reject the null hypothesis that the mere trade motivation of market participant does not affect the informational efficiency of a commodity futures market. This finding remains robust over different trader categories (long-short speculators, index trader, hedger), sub-sample lengths and data frequencies. 


\section{Conclusion}

A central topic in financial economics remains the study of market efficiency and the fac-

tors predominately driving its variation. However, little is known so far about how market efficiency in commodity futures markets varies over time and what role trading motivation plays in driving temporal and cross-sectional variation. This study adresses this gap in the literature by computing time-varying measures of informational efficiency and by analyzing the influence of speculative and hedging activity. We provide evidence for 20 major commodity futures markets over the period January 1986 to May 2019. First of all, we document significant variation in the degree of market efficiency across the markets and time periods. Noteworthy, we find that the financialization period, which is frequently associated with reduced levels of commodity market quality, shows no systematic variation in market efficiency. The fixed effect regressions reveal that speculative activity and heging activity are not significantly related to informational efficiency in commodity futures markets after controlling for other important determinants such as liquidity and volatility. This observation remains valid after considering alternative window lengths and sampling frequencies. Furthermore, a more granular trader categorization considering the heterogeinity among speculators does not alter the conclusion of this paper. Neither long-only index trader nor classic long-short speculators are significantly related to how markets react to the arrival of new information.

An essential implication emerging from the empirical analysis is that regulators should not waste their time discussing the possible diametrically effects of commodity futures market participants on the price formation process. More importantly, they should shift their attentions towards market liquidity and volatility for which we document a significant effect on the degree of informational efficiency. Instead of debating about suggested effects of the financialization period, regulators should focus on containing market volatility and policy reforms that increase trading activity. By doing this, policy makers may affect positively the informational efficiency of asset markets and hence capital allocation decision.

Future research should investigate, whether the documented effect is present in measures 
of market efficiency which go beyond the autocorrelation structure in the return process by relying on high-frequency data. Furthermore, regulators are encouraged to provide scholars with more granular categories for the market participants so that future research may provide insights on which trader groups improve or harm market efficiency. 


\section{References}

Acharya, V. V., Lochstoer, L. A., and Ramadorai, T. (2013). Limits to arbitrage and hedging: Evidence from commodity markets. Journal of Financial Economics, 109(2):441-465.

Amihud, Y. (2002). Illiquidity and stock returns: cross-section and time-series effects. Journal of Financial Markets, 5(1):31-56.

Andrews, D. W. (1991). Asymptotic optimality of generalized cl, cross-validation, and generalized cross-validation in regression with heteroskedastic errors. Journal of Econometrics, $47(2-3): 359-377$.

Barberis, N., Shleifer, A., and Vishny, R. (1998). A model of investor sentiment. Journal of Financial Economics, 49(3):307-343.

Bessembinder, H. (1992). Systematic risk, hedging pressure, and risk premiums in futures markets. The Review of Financial Studies, 5(4):637-667.

Boehmer, E. and Kelley, E. K. (2009). Institutional investors and the informational efficiency of prices. The Review of Financial Studies, 22(9):3563-3594.

Brunetti, C., Büyükşahin, B., and Harris, J. H. (2016). Speculators, prices, and market volatility. Journal of Financial and Quantitative Analysis, 51(5):1545-1574.

Büyükşahin, B. and Robe, M. A. (2014). Speculators, commodities and cross-market linkages. Journal of International Money and Finance, 42:38-70.

Campbell, J. Y., Grossman, S. J., and Wang, J. (1993). Trading volume and serial correlation in stock returns. The Quarterly Journal of Economics, 108(4):905-939.

Chan, K. (1993). Imperfect information and cross-autocorrelation among stock prices. The 415 Journal of Finance, 48(4):1211-1230. 
Chen, Y.-L. and Chang, Y.-K. (2015). Investor structure and the informational efficiency of commodity futures prices. International Review of Financial Analysis, 42:358-367.

Choi, I. (1999). Testing the random walk hypothesis for real exchange rates. Journal of Applied Econometrics, 14(3):293-308.

Chordia, T., Roll, R., and Subrahmanyam, A. (2000). Commonality in liquidity. Journal of Financial Economics, 56(1):3-28.

Chordia, T., Roll, R., and Subrahmanyam, A. (2008). Liquidity and market efficiency. Journal of Financial Economics, 87(2):249-268.

De Bondt, W. F. and Thaler, R. (1985). Does the stock market overreact? The Journal of Finance, 40(3):793-805.

De Long, J. B., Shleifer, A., Summers, L. H., and Waldmann, R. J. (1990). Noise trader risk in financial markets. Journal of Political Economy, 98(4):703-738.

De Roon, F. A., Nijman, T. E., and Veld, C. (2000). Hedging pressure effects in futures markets. The Journal of Finance, 55(3):1437-1456.

Fama, E. (1970). Efficient capital markets: A review of theory and empirical work. The Journal of Finance, 25:383-417.

Froot, K. A., Perold, A. F., et al. (1995). New trading practices and short-run market efficiency. Journal of Futures Markets, 15(7):731-766.

Glosten, L. R. and Milgrom, P. R. (1985). Bid, ask and transaction prices in a specialist market with heterogeneously informed traders. Journal of Financial Economics, 14(1):71100.

Grossman, S. J. and Miller, M. H. (1988). Liquidity and market structure. The Journal of Finance, 43(3):617-633. 
Hamilton, J. D. and Wu, J. C. (2014). Risk premia in crude oil futures prices. Journal of International Money and Finance, 42:9-37.

Hamilton, J. D. and Wu, J. C. (2015). Effects of index-fund investing on commodity futures prices. International Economic Review, 56(1):187-205.

Jegadeesh, N. and Titman, S. (1993). Returns to buying winners and selling losers: Implications for stock market efficiency. The Journal of Finance, 48(1):65-91.

Jensen, M. C. (1978). Some anomalous evidence regarding market efficiency. Journal of Financial Economics, 6(2/3):95-101.

Kyle, A. S. (1985). Continuous auctions and insider trading. Econometrica: Journal of the Econometric Society, 53(6):1315-1335.

Le Pen, Y. and Sévi, B. (2018). Futures trading and the excess co-movement of commodity prices. Review of Finance, 22(1):381-418.

Lo, A. W. and MacKinlay, A. C. (1988). Stock market prices do not follow random walks: Evidence from a simple specification test. The Review of Financial Studies, 1(1):41-66.

Manera, M., Nicolini, M., and Vignati, I. (2016). Modelling futures price volatility in energy markets: Is there a role for financial speculation? Energy Economics, 53:220-229.

McQueen, G., Pinegar, M., and Thorley, S. (1996). Delayed reaction to good news and the cross-autocorrelation of portfolio returns. The Journal of Finance, 51(3):889-919.

Poterba, J. M. and Summers, L. H. (1988). Mean reversion in stock prices: Evidence and implications. Journal of Financial Economics, 22(1):27-59.

Rösch, D. M., Subrahmanyam, A., and Van Dijk, M. A. (2017). The dynamics of market efficiency. The Review of Financial Studies, 30(4):1151-1187. 
Sanders, D. R., Irwin, S. H., and Merrin, R. P. (2010). The adequacy of speculation in agricultural futures markets: Too much of a good thing? Applied Economic Perspectives and Policy, 32(1):77-94.

Sentana, E. and Wadhwani, S. (1992). Feedback traders and stock return autocorrelations: evidence from a century of daily data. The Economic Journal, 102(411):415-425.

Shiller, R. J. (1981). Do stock prices move too much to be justified by subsequent changes in dividends. The American Economic Review, 71(3):421-436.

Working, H. (1960). Speculation on hedging markets. Food Research Institute Studies, 1(1387-2016-116000):185. 
Table 1: Descriptive Statistics Returns

\begin{tabular}{llccccccc}
\hline Contract & Exchange & Min & Mean & Max & St.dev. & Skew. & Kurt. & ADF \\
\hline Chicago Wheat & CBOT & -0.18 & 0.00 & 0.20 & 0.04 & 0.23 & 4.75 & $-32.77^{*}$ \\
Cocoa & ICE & -0.17 & -0.00 & 0.24 & 0.04 & 0.36 & 4.92 & $-33.59^{*}$ \\
Coffee & ICE & -0.33 & -0.00 & 0.28 & 0.05 & 0.10 & 6.23 & $-32.30^{*}$ \\
Copper & COMEX & -0.22 & 0.00 & 0.19 & 0.03 & -0.35 & 5.93 & $-26.56^{*}$ \\
Corn & CBOT & -0.25 & 0.00 & 0.22 & 0.04 & -0.04 & 6.84 & $-30.78^{*}$ \\
Cotton & ICE & -0.75 & -0.00 & 0.17 & 0.04 & -3.24 & 55.82 & $-32.17^{*}$ \\
Crude Oil & NYMEX & -0.28 & 0.00 & 0.31 & 0.05 & -0.25 & 6.63 & $-32.07^{*}$ \\
Feeder Cattle & CME & -0.17 & 0.00 & 0.12 & 0.02 & -0.32 & 6.26 & $-34.81^{*}$ \\
Gold & COMEX & -0.16 & 0.00 & 0.17 & 0.03 & 0.25 & 9.58 & $-33.68^{*}$ \\
Heating Oil & NYMEX & -0.28 & 0.00 & 0.27 & 0.05 & -0.28 & 7.02 & $-33.95^{*}$ \\
Kansas Wheat & KBOT & -0.16 & 0.00 & 0.20 & 0.04 & 0.20 & 5.05 & $-32.87^{*}$ \\
Lean Hogs & CME & -0.29 & 0.00 & 0.29 & 0.05 & 0.02 & 8.65 & $-30.89^{*}$ \\
Live Cattle & CME & -0.17 & 0.00 & 0.11 & 0.02 & -0.38 & 6.07 & $-34.06^{*}$ \\
Natural Gas & NYMEX & -0.37 & 0.00 & 0.48 & 0.07 & 0.17 & 6.10 & $-27.84^{*}$ \\
Palladium & NYMEX & -0.33 & 0.00 & 0.22 & 0.05 & -0.43 & 7.37 & $-32.20^{*}$ \\
Platinum & NYMEX & -0.26 & 0.00 & 0.21 & 0.04 & -0.13 & 8.34 & $-32.23^{*}$ \\
Silver & COMEX & -0.27 & -0.00 & 0.23 & 0.04 & -0.43 & 6.95 & $-32.06^{*}$ \\
Soybeans & CBOT & -0.20 & 0.00 & 0.16 & 0.03 & -0.42 & 5.78 & $-30.75^{*}$ \\
Soybean Oil & CBOT & -0.19 & 0.00 & 0.16 & 0.03 & 0.05 & 4.48 & $-30.88^{*}$ \\
Sugar & ICE & -0.24 & -0.00 & 0.40 & 0.06 & 0.27 & 6.45 & $-33.25^{*}$ \\
\hline
\end{tabular}

Note: The exchange abbreviations CBOT, CME, COMEX, ICE, KBOT and NYMEX refer to the Chicago Board of Trade, the Chicago Mercantile Exchange, the Intercontinental Exchange U.S. (New York), the Kansas Board of Trade and the New York Mercantile Exchange. ${ }^{*}$ denotes statistical significance at the $5 \%$ level.

Table 2: Descriptive Statistics Regression

\begin{tabular}{lccccccc}
\hline Contract & Min & Mean & Max & St.dev. & Skew. & Kurt. & ADF \\
\hline |AVR-1| & 0.00 & 0.08 & 0.47 & 0.08 & 1.33 & 4.70 & $-8.99^{*}$ \\
Total Speculation & 3.55 & 27.78 & 63.14 & 9.86 & 0.49 & 3.01 & $-4.57^{*}$ \\
Working's T & 0.99 & 1.17 & 1.89 & 0.12 & 1.59 & 5.72 & $-1.79^{*}$ \\
Total Hedging & 29.38 & 61.96 & 95.74 & 11.95 & 0.00 & 2.66 & $-2.33^{*}$ \\
Hedging Pressure & -0.40 & 0.09 & 0.74 & 0.17 & 0.68 & 3.84 & $-17.57^{*}$ \\
Volatility & 0.00 & 0.00 & 0.04 & 0.00 & 4.83 & 57.86 & $-18.27^{*}$ \\
Turnover & 0.01 & 0.68 & 4.05 & 0.26 & 0.70 & 4.44 & $-14.49^{*}$ \\
Illiquidity & 0.00 & 0.01 & 4.42 & 0.06 & 28.66 & 1427.29 & $-50.00^{*}$ \\
\hline
\end{tabular}

Note: ${ }^{*}$ denotes statistical significance at the $5 \%$ level. 
Table 3: Mean Deviation from Unity Benchmark

\begin{tabular}{lccc}
\hline \hline & \multicolumn{3}{c}{$\mid$ AVR-1 } \\
\cline { 2 - 4 } & total & pre 2003 & post 2003 \\
\hline Chicago Wheat & 0.050 & 0.052 & 0.049 \\
Chicago Wheat & 0.050 & 0.052 & 0.049 \\
Cocoa & 0.090 & 0.106 & 0.079 \\
Coffee & 0.078 & 0.091 & 0.069 \\
Copper & 0.102 & 0.105 & 0.100 \\
Corn & 0.064 & 0.063 & 0.065 \\
Cotton & 0.098 & 0.090 & 0.104 \\
Crude Oil & 0.156 & 0.254 & 0.092 \\
Feeder Cattle & 0.060 & 0.066 & 0.056 \\
Gold & 0.034 & 0.046 & 0.025 \\
Heating Oil & 0.114 & 0.182 & 0.067 \\
Kansas Wheat & 0.046 & 0.033 & 0.054 \\
Lean Hogs & 0.118 & 0.077 & 0.135 \\
Live Cattle & 0.042 & 0.028 & 0.052 \\
Natural Gas & 0.079 & 0.167 & 0.036 \\
Palladium & 0.093 & 0.059 & 0.113 \\
Platinum & 0.065 & 0.084 & 0.052 \\
Silver & 0.050 & 0.071 & 0.036 \\
Soybeans & 0.084 & 0.067 & 0.096 \\
Soybean Oil & 0.058 & 0.072 & 0.048 \\
Sugar & 0.106 & 0.141 & 0.082 \\
\hline
\end{tabular}

Note: Table 3 reports the the mean absolute deviation of the Automatic Variance Ratio proposed by Choi (1999) from unity. The metric is computed for the total sample as well as for sub-samples spanning the pre- and postfinancialization period. 
Table 4: Regression Speculative Activity - Window Size 250 Weeks

\begin{tabular}{|c|c|c|c|c|c|c|}
\hline & \multicolumn{3}{|c|}{ Total Speculation } & \multicolumn{3}{|c|}{ Excess Speculation } \\
\hline & $(1)$ & $(2)$ & $(3)$ & $(4)$ & $(5)$ & $(6)$ \\
\hline Lag & & $\begin{array}{c}0.989^{* * *} \\
(0.001)\end{array}$ & $\begin{array}{c}0.986^{* * *} \\
(0.001)\end{array}$ & & $\begin{array}{c}0.989^{* * *} \\
(0.001)\end{array}$ & $\begin{array}{c}0.986^{* * *} \\
(0.001)\end{array}$ \\
\hline Speculation & $\begin{array}{c}-0.001^{*} \\
(0.001)\end{array}$ & $\begin{array}{c}-0.00002^{* *} \\
(0.00001)\end{array}$ & $\begin{array}{c}0.00002 \\
(0.00001)\end{array}$ & & & \\
\hline Volatility & & & $\begin{array}{c}0.409^{* * *} \\
(0.129)\end{array}$ & & & $\begin{array}{c}0.405^{* * *} \\
(0.129)\end{array}$ \\
\hline Turnover & & & $\begin{array}{c}-0.001^{* * *} \\
(0.0003)\end{array}$ & & & $\begin{array}{c}-0.001^{* * *} \\
(0.0003)\end{array}$ \\
\hline Illiquidity & & & $\begin{array}{c}0.004^{* * *} \\
(0.001)\end{array}$ & & & $\begin{array}{c}0.004^{* * *} \\
(0.001)\end{array}$ \\
\hline Workings $\mathrm{T}$ & & & & $\begin{array}{c}-0.083^{* *} \\
(0.040)\end{array}$ & $\begin{array}{l}-0.001 \\
(0.001)\end{array}$ & $\begin{array}{c}0.001 \\
(0.001)\end{array}$ \\
\hline Constant & $\begin{array}{c}0.115^{* * *} \\
(0.022)\end{array}$ & $\begin{array}{l}0.001^{* * *} \\
(0.0002)\end{array}$ & $\begin{array}{c}0.004 \\
(0.006)\end{array}$ & $\begin{array}{c}0.177^{* * *} \\
(0.051)\end{array}$ & $\begin{array}{l}0.002^{* *} \\
(0.001)\end{array}$ & $\begin{array}{c}0.003 \\
(0.006)\end{array}$ \\
\hline $\begin{array}{l}\text { Commdity FE } \\
\text { Year FE }\end{array}$ & $\begin{array}{l}\text { No } \\
\text { No }\end{array}$ & $\begin{array}{l}\text { No } \\
\text { No }\end{array}$ & $\begin{array}{l}\text { Yes } \\
\text { Yes }\end{array}$ & $\begin{array}{l}\text { No } \\
\text { No }\end{array}$ & $\begin{array}{l}\text { No } \\
\text { No }\end{array}$ & $\begin{array}{l}\text { Yes } \\
\text { Yes }\end{array}$ \\
\hline Adjusted $\mathrm{R}^{2}$ & 0.026 & 0.979 & 0.979 & 0.017 & 0.979 & 0.979 \\
\hline
\end{tabular}

Note: Table 4 reports the pooled OLS regression results for Equation 14. The dependent variable is the absolute deviation of the AVR from unity $\mid$ AVR-1| for commodity market $i$ at time period $t$. The regression allows for clustering among observations of the same commodity futures market and standard errors are reported in parantheses. ${ }^{* * *},{ }^{* *}$ and ${ }^{*}$ denote statistical significance at the $1 \%, 5 \%$ and $10 \%$ level, respectively. The window size for the moving-subsample is 250 weeks. 
Table 5: Regression Hedging Activity - Window Size 250 Weeks

\begin{tabular}{|c|c|c|c|c|c|c|}
\hline & \multicolumn{3}{|c|}{ Total Hedging } & \multicolumn{3}{|c|}{ Hedging Pressure } \\
\hline & $(1)$ & $(2)$ & (3) & (4) & $(5)$ & $(6)$ \\
\hline Lag & & $\begin{array}{c}0.988^{* * *} \\
(0.001)\end{array}$ & $\begin{array}{c}0.986^{* * *} \\
(0.001)\end{array}$ & & $\begin{array}{c}0.989^{* * *} \\
(0.001)\end{array}$ & $\begin{array}{c}0.986^{* * *} \\
(0.001)\end{array}$ \\
\hline Hedging Total & $\begin{array}{l}0.002^{* *} \\
(0.001)\end{array}$ & $\begin{array}{l}0.00002^{* *} \\
(0.00001)\end{array}$ & $\begin{array}{c}0.00001 \\
(0.00002)\end{array}$ & & & \\
\hline Volatility & & & $\begin{array}{c}0.393^{* * *} \\
(0.123)\end{array}$ & & & $\begin{array}{c}0.398^{* * *} \\
(0.127)\end{array}$ \\
\hline Turnover & & & $\begin{array}{c}-0.001^{* * *} \\
(0.0003)\end{array}$ & & & $\begin{array}{c}-0.001^{* * *} \\
(0.0003)\end{array}$ \\
\hline Illiquidity & & & $\begin{array}{c}0.004^{* * *} \\
(0.001)\end{array}$ & & & $\begin{array}{c}0.004^{* * *} \\
(0.001)\end{array}$ \\
\hline Hedging Pressure & & & & $\begin{array}{l}-0.019 \\
(0.028)\end{array}$ & $\begin{array}{c}-0.001 \\
(0.0004)\end{array}$ & $\begin{array}{l}0.0002 \\
(0.001)\end{array}$ \\
\hline Constant & $\begin{array}{l}-0.020 \\
(0.037)\end{array}$ & $\begin{array}{c}-0.0004 \\
(0.001)\end{array}$ & $\begin{array}{c}0.004 \\
(0.006)\end{array}$ & $\begin{array}{c}0.081^{* * *} \\
(0.008)\end{array}$ & $\begin{array}{l}0.001^{* * *} \\
(0.0001)\end{array}$ & $\begin{array}{c}0.005 \\
(0.006)\end{array}$ \\
\hline Commdity FE & No & No & Yes & No & No & Yes \\
\hline Year FE & No & No & Yes & No & No & Yes \\
\hline Adjusted $\mathrm{R}^{2}$ & 0.06 & 0.979 & 0.979 & 0.002 & 0.979 & 0.979 \\
\hline
\end{tabular}

Note: Table 5 reports the pooled OLS regression results for Equation 14. The dependent variable is the absolute deviation of the AVR from unity |AVR-1| for commodity market $i$ at time period $t$. The regression allows for clustering among observations of the same commodity futures market and standard errors are reported in parantheses. ${ }^{* * *},{ }^{* *}$ and ${ }^{*}$ denote statistical significance at the $1 \%, 5 \%$ and $10 \%$ level, respectively. The window size for the moving-subsample is 250 weeks. 
Table 6: Regression Speculative Activity - Window Size 100 Weeks

\begin{tabular}{|c|c|c|c|c|c|c|}
\hline & \multicolumn{3}{|c|}{ Total Speculation } & \multicolumn{3}{|c|}{ Excess Speculation } \\
\hline & (1) & $(2)$ & (3) & (4) & $(5)$ & (6) \\
\hline Lag & & $\begin{array}{c}0.969^{* * *} \\
(0.002)\end{array}$ & $\begin{array}{c}0.965^{* * *} \\
(0.002)\end{array}$ & & $\begin{array}{c}0.969^{* * *} \\
(0.002)\end{array}$ & $\begin{array}{c}0.965^{* * *} \\
(0.002)\end{array}$ \\
\hline Speculation & $\begin{array}{l}-0.0003 \\
(0.0004)\end{array}$ & $\begin{array}{c}-0.00001 \\
(0.00001)\end{array}$ & $\begin{array}{c}0.0001 \\
(0.00003)\end{array}$ & & & \\
\hline Volatility & & & $\begin{array}{c}0.754^{* * *} \\
(0.186)\end{array}$ & & & $\begin{array}{c}0.735^{* * *} \\
(0.181)\end{array}$ \\
\hline Turnover & & & $\begin{array}{c}-0.003^{* * *} \\
(0.001)\end{array}$ & & & $\begin{array}{c}-0.003^{* * *} \\
(0.001)\end{array}$ \\
\hline Illiquidity & & & $\begin{array}{c}0.014^{* * *} \\
(0.003)\end{array}$ & & & $\begin{array}{c}0.013^{* * *} \\
(0.003)\end{array}$ \\
\hline Workings $\mathrm{T}$ & & & & $\begin{array}{l}-0.029 \\
(0.033)\end{array}$ & $\begin{array}{c}-0.0005 \\
(0.001)\end{array}$ & $\begin{array}{c}0.001 \\
(0.003)\end{array}$ \\
\hline Constant & $\begin{array}{c}0.110^{* * *} \\
(0.010)\end{array}$ & $\begin{array}{l}0.003^{* * *} \\
(0.0005)\end{array}$ & $\begin{array}{c}0.002 \\
(0.011)\end{array}$ & $\begin{array}{c}0.137^{* * *} \\
(0.039)\end{array}$ & $\begin{array}{c}0.004^{* * *} \\
(0.001)\end{array}$ & $\begin{array}{c}0.002 \\
(0.010)\end{array}$ \\
\hline Commdity FE & No & No & Yes & No & No & Yes \\
\hline Year FE & No & No & Yes & No & No & Yes \\
\hline Adjusted $\mathrm{R}^{2}$ & 0.001 & 0.939 & 0.939 & 0.001 & 0.939 & 0.939 \\
\hline
\end{tabular}

Note: Table 6 reports the pooled OLS regression results for Equation 14. The dependent variable is the absolute deviation of the AVR from unity $\mid$ AVR-1| for commodity market $i$ at time period $t$. The regression allows for clustering among observations of the same commodity futures market and standard errors are reported in parantheses. ${ }^{* * *}{ }^{* *}$ and * denote statistical significance at the $1 \%, 5 \%$ and $10 \%$ level, respectively. The window size for the moving-subsample is 100 weeks. 
Table 7: Regression Speculative Activity - Window Size 400 Weeks

\begin{tabular}{|c|c|c|c|c|c|c|}
\hline & \multicolumn{3}{|c|}{ Total Speculation } & \multicolumn{3}{|c|}{ Excess Speculation } \\
\hline & (1) & $(2)$ & $(3)$ & (4) & $(5)$ & (6) \\
\hline Lag & & $\begin{array}{c}0.994^{* * *} \\
(0.001)\end{array}$ & $\begin{array}{c}0.991^{* * *} \\
(0.001)\end{array}$ & & $\begin{array}{c}0.994^{* * *} \\
(0.001)\end{array}$ & $\begin{array}{c}0.991^{* * *} \\
(0.001)\end{array}$ \\
\hline Speculation & $\begin{array}{c}-0.002^{*} \\
(0.001)\end{array}$ & $\begin{array}{l}-0.00001 \\
(0.00001)\end{array}$ & $\begin{array}{c}0.00001 \\
(0.00001)\end{array}$ & & & \\
\hline Volatility & & & $\begin{array}{c}0.146^{* * *} \\
(0.051)\end{array}$ & & & $\begin{array}{c}0.144^{* * *} \\
(0.049)\end{array}$ \\
\hline Turnover & & & $\begin{array}{c}-0.001^{* * *} \\
(0.0002)\end{array}$ & & & $\begin{array}{c}-0.001^{* * *} \\
(0.0002)\end{array}$ \\
\hline Illiquidity & & & $\begin{array}{l}0.0001 \\
(0.001)\end{array}$ & & & $\begin{array}{c}0.00004 \\
(0.001)\end{array}$ \\
\hline Workings $\mathrm{T}$ & & & & $\begin{array}{c}-0.091^{*} \\
(0.049)\end{array}$ & $\begin{array}{l}-0.0004 \\
(0.0004)\end{array}$ & $\begin{array}{c}0.001 \\
(0.001)\end{array}$ \\
\hline Constant & $\begin{array}{c}0.117^{* * *} \\
(0.030)\end{array}$ & $\begin{array}{l}0.001^{* * *} \\
(0.0002)\end{array}$ & $\begin{array}{l}-0.006 \\
(0.007)\end{array}$ & $\begin{array}{c}0.177^{* * *} \\
(0.064)\end{array}$ & $\begin{array}{c}0.001^{* *} \\
(0.0004)\end{array}$ & $\begin{array}{l}-0.006 \\
(0.008)\end{array}$ \\
\hline Commdity FE & No & No & Yes & No & No & Yes \\
\hline Year FE & No & No & Yes & No & No & Yes \\
\hline Adjusted $\mathrm{R}^{2}$ & 0.054 & 0.988 & 0.988 & 0.026 & 0.988 & 0.988 \\
\hline
\end{tabular}

Note: Table 7 reports the pooled OLS regression results for Equation 14. The dependent variable is the absolute deviation of the AVR from unity |AVR-1| for commodity market $i$ at time period $t$. The regression allows for clustering among observations of the same commodity futures market and standard errors are reported in parantheses. ${ }^{* * *},{ }^{* *}$ and * denote statistical significance at the $1 \%, 5 \%$ and $10 \%$ level, respectively. The window size for the moving-subsample is 400 weeks. 
Table 8: Regression Hedging Activity - Window Size 100 Weeks

\begin{tabular}{|c|c|c|c|c|c|c|}
\hline & \multicolumn{3}{|c|}{ Total Hedging } & \multicolumn{3}{|c|}{ Hedging Pressure } \\
\hline & $(1)$ & $(2)$ & $(3)$ & $(4)$ & $(5)$ & $(6)$ \\
\hline Lag & & $\begin{array}{c}0.969^{* * *} \\
(0.002)\end{array}$ & $\begin{array}{c}0.965^{* * *} \\
(0.002)\end{array}$ & & $\begin{array}{c}0.969^{* * *} \\
(0.002)\end{array}$ & $\begin{array}{c}0.965^{* * *} \\
(0.002)\end{array}$ \\
\hline Hedging Total & $\begin{array}{c}0.001^{* *} \\
(0.0004)\end{array}$ & $\begin{array}{l}0.00003^{* *} \\
(0.00001)\end{array}$ & $\begin{array}{c}0.00002 \\
(0.00002)\end{array}$ & & & \\
\hline Volatility & & & $\begin{array}{c}0.718^{* * *} \\
(0.185)\end{array}$ & & & $\begin{array}{c}0.728^{* * *} \\
(0.181)\end{array}$ \\
\hline Turnover & & & $\begin{array}{c}-0.002^{* * *} \\
(0.001)\end{array}$ & & & $\begin{array}{c}-0.003^{* * *} \\
(0.001)\end{array}$ \\
\hline Illiquidity & & & $\begin{array}{c}0.013^{* * *} \\
(0.003)\end{array}$ & & & $\begin{array}{c}0.014^{* * *} \\
(0.003)\end{array}$ \\
\hline Hedging Pressure & & & & $\begin{array}{l}-0.010 \\
(0.023)\end{array}$ & $\begin{array}{l}-0.001 \\
(0.001)\end{array}$ & $\begin{array}{c}0.001 \\
(0.001)\end{array}$ \\
\hline Constant & $\begin{array}{l}0.054^{* *} \\
(0.026)\end{array}$ & $\begin{array}{c}0.001^{*} \\
(0.001)\end{array}$ & $\begin{array}{c}0.002 \\
(0.012)\end{array}$ & $\begin{array}{c}0.104^{* * *} \\
(0.005)\end{array}$ & $\begin{array}{c}0.003^{* * *} \\
(0.0003)\end{array}$ & $\begin{array}{c}0.003 \\
(0.011)\end{array}$ \\
\hline Commdity FE & No & No & Yes & No & No & Yes \\
\hline Year FE & No & No & Yes & No & No & Yes \\
\hline Adjusted $\mathrm{R}^{2}$ & 0.008 & 0.939 & 0.939 & 0.001 & 0.939 & 0.939 \\
\hline
\end{tabular}

Note: Table 8 reports the pooled OLS regression results for Equation 14. The dependent variable is the absolute deviation of the AVR from unity |AVR-1| for commodity market $i$ at time period $t$. The regression allows for clustering among observations of the same commodity futures market and standard errors are reported in parantheses. ${ }^{* * *},{ }^{* *}$ and ${ }^{*}$ denote statistical significance at the $1 \%, 5 \%$ and $10 \%$ level, respectively. The window size for the moving-subsample is 100 weeks. 
Table 9: Regression Hedging Activity - Window Size 400 Weeks

\begin{tabular}{|c|c|c|c|c|c|c|}
\hline & \multicolumn{3}{|c|}{ Total Hedging } & \multicolumn{3}{|c|}{ Hedging Pressure } \\
\hline Lag & (1) & $\begin{array}{c}(2) \\
0.993^{* * *} \\
(0.001)\end{array}$ & $\begin{array}{c}(3) \\
0.991^{* * *} \\
(0.001)\end{array}$ & $(4)$ & $\begin{array}{c}(5) \\
0.994^{* * *} \\
(0.001)\end{array}$ & $\begin{array}{c}(6) \\
0.991^{* * *} \\
(0.001)\end{array}$ \\
\hline Hedging Total & $\begin{array}{l}0.002^{* *} \\
(0.001)\end{array}$ & $\begin{array}{l}0.00001^{*} \\
(0.00001)\end{array}$ & $\begin{array}{c}0.00000 \\
(0.00001)\end{array}$ & & & \\
\hline Volatility & & & $\begin{array}{c}0.138^{* * *} \\
(0.052)\end{array}$ & & & $\begin{array}{c}0.141^{* * *} \\
(0.049)\end{array}$ \\
\hline Turnover & & & $\begin{array}{c}-0.001^{\text {*** }} \\
(0.0002)\end{array}$ & & & $\begin{array}{c}-0.001^{* * *} \\
(0.0002)\end{array}$ \\
\hline Illiquidity & & & $\begin{array}{c}-0.00003 \\
(0.001)\end{array}$ & & & $\begin{array}{l}0.00002 \\
(0.0005)\end{array}$ \\
\hline Hedging Pressure & & & & $\begin{array}{l}-0.028 \\
(0.026)\end{array}$ & $\begin{array}{l}-0.0002 \\
(0.0002)\end{array}$ & $\begin{array}{c}-0.00001 \\
(0.0004)\end{array}$ \\
\hline Constant & $\begin{array}{l}-0.035 \\
(0.043)\end{array}$ & $\begin{array}{l}-0.0002 \\
(0.0003)\end{array}$ & $\begin{array}{l}-0.006 \\
(0.007)\end{array}$ & $\begin{array}{c}0.073^{* * *} \\
(0.010)\end{array}$ & $\begin{array}{c}0.0004^{* * *} \\
(0.0001)\end{array}$ & $\begin{array}{l}-0.006 \\
(0.007)\end{array}$ \\
\hline $\begin{array}{l}\text { Commdity FE } \\
\text { Year FE }\end{array}$ & $\begin{array}{l}\text { No } \\
\text { No }\end{array}$ & $\begin{array}{l}\text { No } \\
\text { No }\end{array}$ & $\begin{array}{l}\text { Yes } \\
\text { Yes }\end{array}$ & $\begin{array}{l}\mathrm{No} \\
\mathrm{No}\end{array}$ & $\begin{array}{l}\text { No } \\
\text { No }\end{array}$ & $\begin{array}{l}\text { Yes } \\
\text { Yes }\end{array}$ \\
\hline Adjusted $\mathrm{R}^{2}$ & 0.083 & 0.988 & 0.988 & 0.005 & 0.988 & 0.988 \\
\hline
\end{tabular}

Note: Table 7 reports the pooled OLS regression results for Equation 14. The dependent variable is the absolute deviation of the AVR from unity |AVR-1| for commodity market $i$ at time period $t$. The regression allows for clustering among observations of the same commodity futures market and standard errors are reported in parantheses. ${ }^{* * *},{ }^{* *}$ and * denote statistical significance at the $1 \%, 5 \%$ and $10 \%$ level, respectively. The window size for the moving-subsample is 400 weeks. 
Table 10: Regression Speculative Activity - Window Size 1000 Days

\begin{tabular}{|c|c|c|c|c|c|c|}
\hline & \multicolumn{3}{|c|}{ Total Speculation } & \multicolumn{3}{|c|}{ Excess Speculation } \\
\hline & $(1)$ & $(2)$ & $(3)$ & $(4)$ & $(5)$ & $(6)$ \\
\hline Lag & & $\begin{array}{c}0.993^{* * *} \\
(0.001)\end{array}$ & $\begin{array}{c}0.991^{* * *} \\
(0.001)\end{array}$ & & $\begin{array}{c}0.993^{* * *} \\
(0.001)\end{array}$ & $\begin{array}{c}0.991^{* * *} \\
(0.001)\end{array}$ \\
\hline Speculation & $\begin{array}{c}0.001 \\
(0.001)\end{array}$ & $\begin{array}{c}0.00001^{*} \\
(0.00000)\end{array}$ & $\begin{array}{c}0.00000 \\
(0.00001)\end{array}$ & & & \\
\hline Volatility & & & $\begin{array}{c}-0.029^{* * *} \\
(0.001)\end{array}$ & & & $\begin{array}{c}-0.029^{* * *} \\
(0.001)\end{array}$ \\
\hline Turnover & & & $\begin{array}{c}0.001 \\
(0.001)\end{array}$ & & & $\begin{array}{c}0.001 \\
(0.001)\end{array}$ \\
\hline Illiquidity & & & $\begin{array}{c}3.169^{* * *} \\
(0.750)\end{array}$ & & & $\begin{array}{c}3.013^{* * *} \\
(0.692)\end{array}$ \\
\hline Workings $\mathrm{T}$ & & & & $\begin{array}{c}0.094 \\
(0.077)\end{array}$ & $\begin{array}{c}0.001 \\
(0.0004)\end{array}$ & $\begin{array}{c}-0.0004 \\
(0.001)\end{array}$ \\
\hline Constant & $\begin{array}{c}0.028 \\
(0.022)\end{array}$ & $\begin{array}{c}0.0002 \\
(0.0001)\end{array}$ & $\begin{array}{c}0.001 \\
(0.001)\end{array}$ & $\begin{array}{l}-0.048 \\
(0.089)\end{array}$ & $\begin{array}{l}-0.0003 \\
(0.0005)\end{array}$ & $\begin{array}{c}0.001 \\
(0.001)\end{array}$ \\
\hline Commdity FE & No & No & Yes & No & No & Yes \\
\hline Year FE & No & No & Yes & No & No & Yes \\
\hline Adjusted $\mathrm{R}^{2}$ & 0.037 & 0.987 & 0.987 & 0.036 & 0.987 & 0.987 \\
\hline
\end{tabular}

Note: Table 10 reports the pooled OLS regression results for Equation 14. The dependent variable is the absolute deviation of the AVR from unity |AVR-1| for commodity market $i$ at time period $t$. The regression allows for clustering among observations of the same commodity futures market and standard errors are reported in parantheses. ***,** and ${ }^{*}$ denote statistical significance at the $1 \%, 5 \%$ and $10 \%$ level, respectively. The window size for the moving-subsample is 1000 days. 
Table 11: Regression Hedging Activity - Window Size 1000 Days

\begin{tabular}{|c|c|c|c|c|c|c|}
\hline & \multicolumn{3}{|c|}{ Total Hedging } & \multicolumn{3}{|c|}{ Hedging Pressure } \\
\hline & (1) & $(2)$ & $(3)$ & $(4)$ & $(5)$ & $(6)$ \\
\hline Lag & & $\begin{array}{c}0.993^{* * *} \\
(0.001)\end{array}$ & $\begin{array}{c}0.991^{* * *} \\
(0.001)\end{array}$ & & $\begin{array}{c}0.993^{* * *} \\
(0.001)\end{array}$ & $\begin{array}{c}0.991^{* * *} \\
(0.001)\end{array}$ \\
\hline Hedging Total & $\begin{array}{l}-0.001 \\
(0.001)\end{array}$ & $\begin{array}{l}-0.00000 \\
(0.00000)\end{array}$ & $\begin{array}{c}0.00000 \\
(0.00001)\end{array}$ & & & \\
\hline Volatility & & & $\begin{array}{c}-0.029^{* * *} \\
(0.001)\end{array}$ & & & $\begin{array}{c}-0.029^{* * *} \\
(0.001)\end{array}$ \\
\hline Turnover & & & $\begin{array}{c}0.001 \\
(0.001)\end{array}$ & & & $\begin{array}{c}0.001 \\
(0.001)\end{array}$ \\
\hline Illiquidity & & & $\begin{array}{c}2.968^{* * *} \\
(0.699)\end{array}$ & & & $\begin{array}{c}3.214^{* * *} \\
(0.931)\end{array}$ \\
\hline Hedging Pressure & & & & $\begin{array}{c}0.018 \\
(0.021)\end{array}$ & $\begin{array}{l}0.00002 \\
(0.0003)\end{array}$ & $\begin{array}{c}0.0001 \\
(0.0004)\end{array}$ \\
\hline Constant & $\begin{array}{l}0.109^{* *} \\
(0.050)\end{array}$ & $\begin{array}{c}0.001^{* *} \\
(0.0003)\end{array}$ & $\begin{array}{l}0.0004 \\
(0.001)\end{array}$ & $\begin{array}{c}0.062^{* * *} \\
(0.009)\end{array}$ & $\begin{array}{c}0.0004^{* * *} \\
(0.0001)\end{array}$ & $\begin{array}{c}0.001 \\
(0.001)\end{array}$ \\
\hline $\begin{array}{l}\text { Commdity FE } \\
\text { Year FE }\end{array}$ & $\begin{array}{l}\mathrm{No} \\
\mathrm{No}\end{array}$ & $\begin{array}{l}\text { No } \\
\text { No }\end{array}$ & $\begin{array}{l}\text { Yes } \\
\text { Yes }\end{array}$ & $\begin{array}{l}\text { No } \\
\text { No }\end{array}$ & $\begin{array}{l}\text { No } \\
\text { No }\end{array}$ & $\begin{array}{l}\text { Yes } \\
\text { Yes }\end{array}$ \\
\hline Adjusted $\mathrm{R}^{2}$ & 0.018 & 0.987 & 0.987 & 0.002 & 0.987 & 0.987 \\
\hline
\end{tabular}

Note: Table 11 reports the pooled OLS regression results for Equation 14. The dependent variable is the absolute deviation of the AVR from unity |AVR-1| for commodity market $i$ at time period $t$. The regression allows for clustering among observations of the same commodity futures market and standard errors are reported in parantheses. ${ }^{* * *},{ }^{* *}$ and * denote statistical significance at the $1 \%, 5 \%$ and $10 \%$ level, respectively. The window size for the moving-subsample is 1000 days. 
Table 12: Regression Index Investor Activity Window Size 250 Weeks

\begin{tabular}{lccc}
\hline & \multicolumn{3}{c}{ Index Investor } \\
\cline { 2 - 4 } & & $(1)$ & $(3)$ \\
\hline Lag & & $0.986^{* * *}$ & $0.984^{* * *}$ \\
& & $(0.002)$ & $(0.003)$ \\
Index Investor & -0.007 & 0.0001 & 0.0002 \\
& $(0.005)$ & $(0.0001)$ & $(0.0002)$ \\
Volatility & & & -0.120 \\
& & & $(1.307)$ \\
Turnover & & & $-0.010^{*}$ \\
& & & $(0.005)$ \\
Illiquidity & & & -0.922 \\
& & & $(0.676)$ \\
Constant & & & 0.005 \\
& & & $(0.010)$ \\
\hline Year FE & & & Yes \\
\hline Adjusted R ${ }^{2}$ & 0.968 & 0.982 & 0.968 \\
\hline
\end{tabular}

Note: Table 12 reports the pooled OLS regression results for Equation 14. The dependent variable is the absolute deviation of the AVR from unity |AVR-1| for commodity market $i$ at time period $t$. The regression allows for clustering among observations of the same commodity futures market and standard errors are reported in parantheses. ${ }^{* * *},{ }^{* *}$ and ${ }^{*}$ denote statistical significance at the 1\%,5\% and 10\% level, respectively. The window size for the moving-subsample is 250 weeks. 
(a) Grain \& Oil Seeds

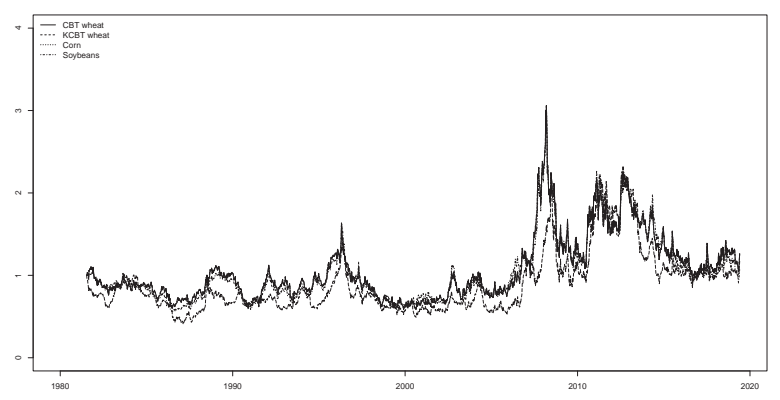

(c) Meat

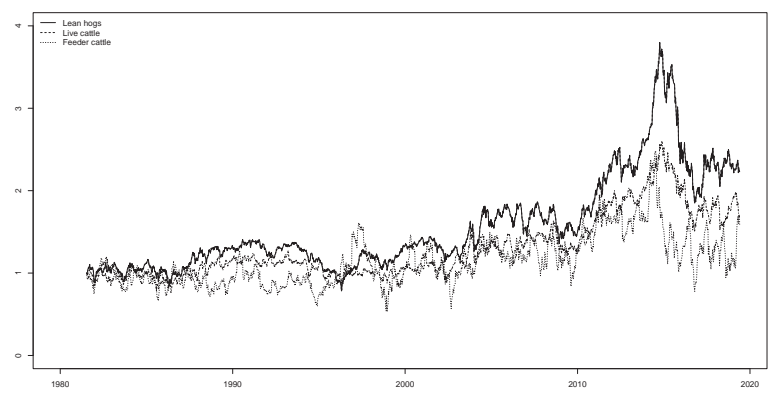

(b) Softs

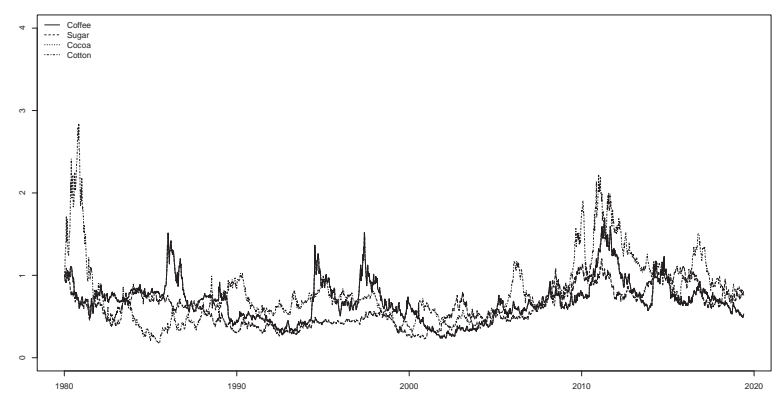

(d) Energy

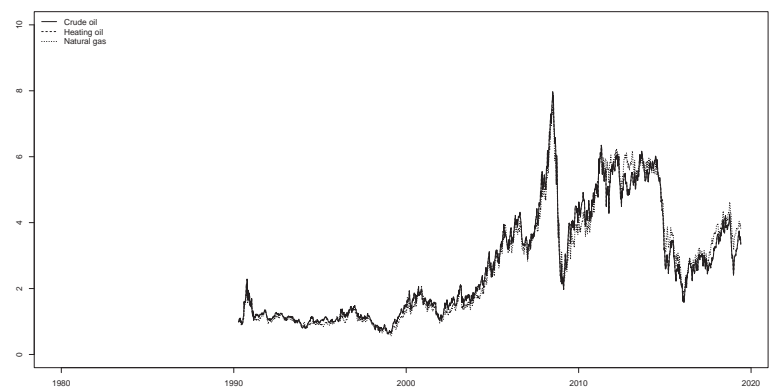

(e) Metals

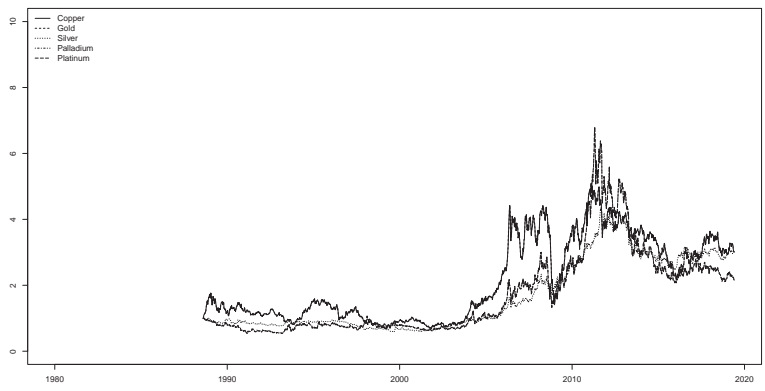

Figure 1: Time-Series

Note: The graphs show the time-varying absolute deviation from the random walk benchmark process of each futures contract. Values above unity indicate that a positive autocorrelation is present, whereas values below unity suggest the opposite. 
(a) Chicago Wheat - CBOT

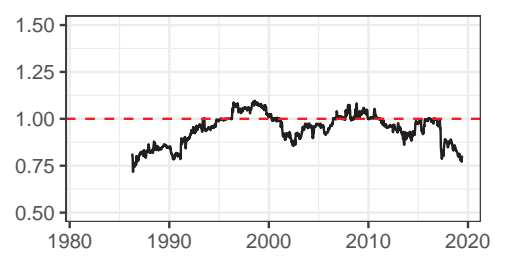

(d) Copper - COMEX

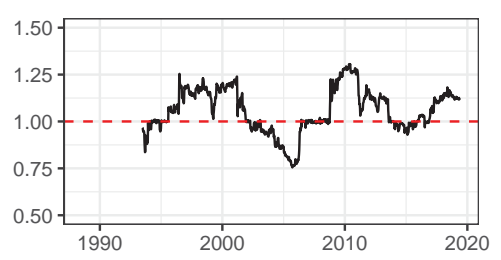

(g) Crude Oil - NYMEX

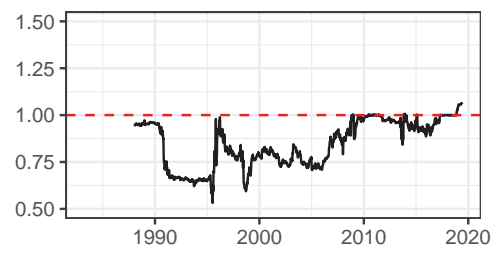

(j) Heating Oil - NYMEX

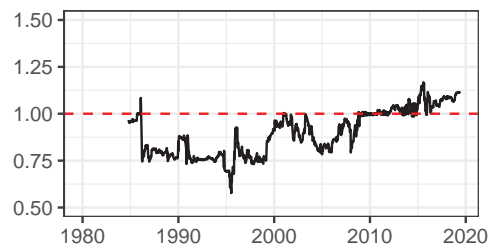

(m) Live Cattle - CME

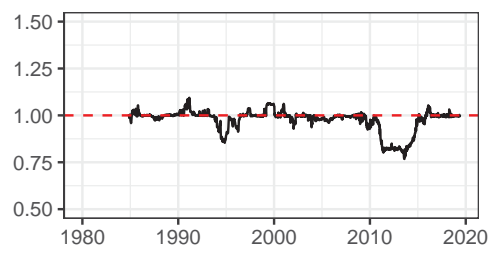

(b) Cocoa - ICE

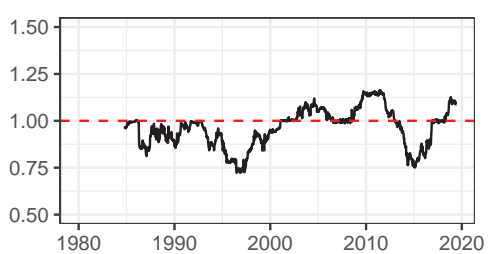

(e) Corn - CBOT

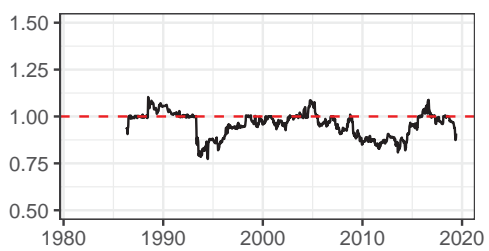

(h) Feeder Cattle - CME

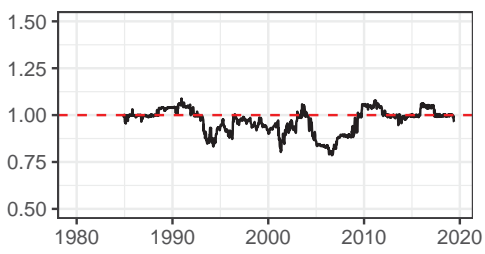

(k) Kansas Wheat - KBOT

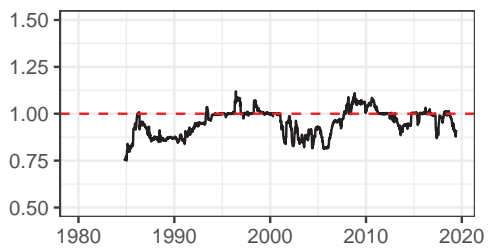

(n) Natural Gas - NYMEX

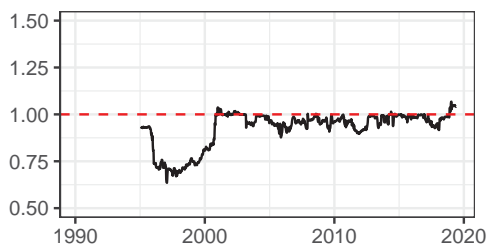

(c) Coffee - ICE

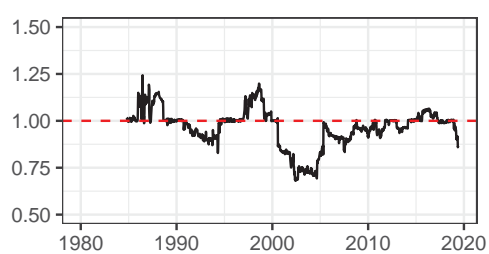

(f) Cotton - ICE

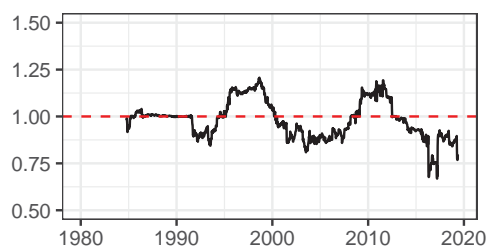

(i) Gold - COMEX

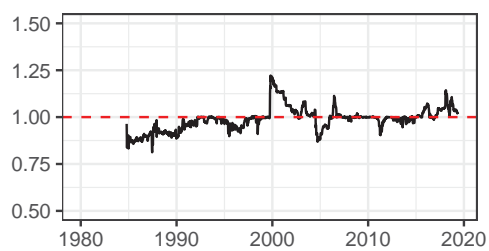

(l) Lean Hogs - CME

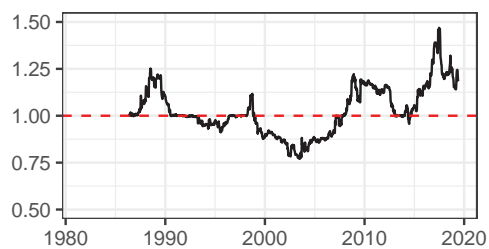

(o) Palladium - NYMEX

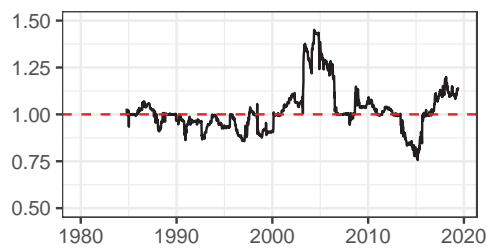

Figure 2: Time-Varying Degree of Informational Efficiency

Note: The graphs show the time-varying absolute deviation from the random walk benchmark process of each futures contract. Values above unity indicate that a positive autocorrelation is present, whereas values below unity suggest the opposite. 
(a) Platinum - NYMEX

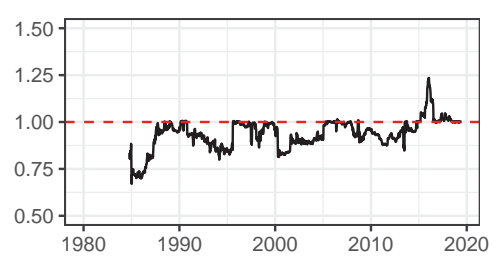

(b) Silver - COMEX

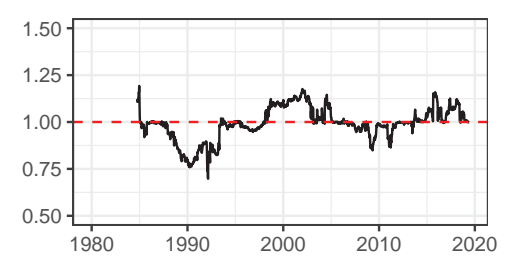

(c) Soybean Oil - CBOT

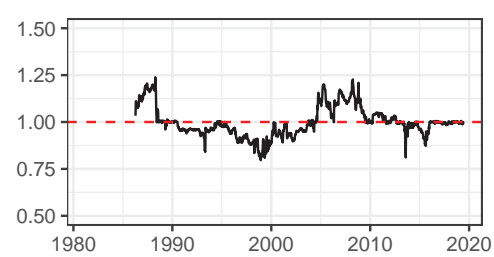

(d) Soybeans - CBOT

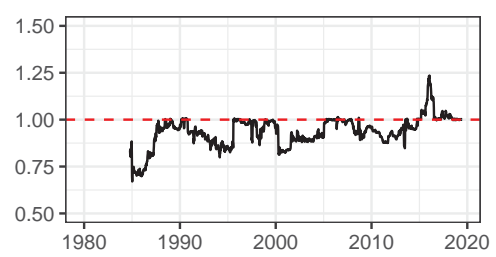

(e) Sugar - ICE

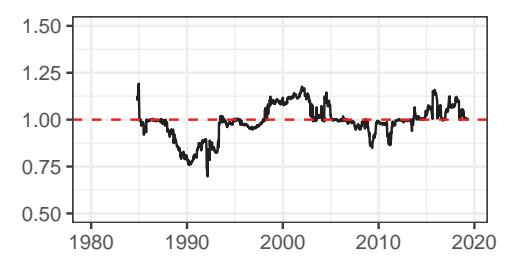

Figure 2: Time-Varying Degree of Informational Efficiency 